\title{
An immunoperoxidase assay for the detection of specific IgA antibody in Epstein-Barr virus infections
}

\author{
R CEVENINI, M DONATI, F RUMPIANESI, A MORONI, P PAOLUCCI,*
}

From the Institute of Microbiology and *III Department of Paediatrics, University of Bologna, Ospedale $S$ Orsola, Via Massarenti 9, 40138 Bologna, Italy

SUMMARY A technique using indirect immunoperoxidase antibody was developed for the detection of specific serum IgA antibody to Epstein-Barr virus capsid antigen and early antigen. The IgA technique was compared with an immunofluorescence antibody method. Epstein-Barr virus IgA antibody against viral capsid antigen was detected in all nine patients with Epstein-Barr virus associated undifferentiated nasopharyngeal carcinoma, in $13(72 \cdot 2 \%)$ of 18 patients with infectious mononucleosis, in $21(28 \cdot 3 \%)$ of 74 patients with acute lymphoblastic leukaemia, and in six $(20 \%)$ of 30 patients who had recently had kidney transplants. Epstein-Barr virus IgA antibody against viral capsid antigen was also detected in four $(10 \%)$ of 40 healthy subjects, but it was not found in any of 20 cord blood samples. Epstein-Barr virus IgA antibody to early antigen was detected in six $(66.6 \%)$ patients with nasopharyngeal carcinoma and in two $(2.7 \%)$ patients with acute lymphoblastic leukaemia. The immunoperoxidase assay for Epstein-Barr virus specific IgA was simple, reliable, and rapid and correlated well $(r=0.94)$ with the immunofluorescence antibody technique.

The Epstein-Barr virus, which is the cause of infectious mononucleosis ${ }^{1}$ and possibly of nasopharyngeal carcinoma and Birkitt's lymphoma, ${ }^{2}$ is one of the commonest infectious agents in man, as suggested by many serological studies. In infancy and childhood, however, Epstein-Barr virus infections are usually subclinical.

The immunofluorescence assay, which determines titres of antibody to several virus specific antigens and their immunoglobulin class, is the most widely used technique for the specific diagnosis of Epstein-Barr virus infections. ${ }^{3}$ Recently, other methods such as enzyme immunoassay, ${ }^{4}$ and immune adherence haemagglutination techniques ${ }^{5}$ have been developed, aiming to replace immunofluorescence. However, a considerable degree of purity of test antigens is required to avoid interaction of non-specific antibodies and to differentiate between the various Epstein-Barr virus specific antigens. The immunoperoxidase technique has proved to be a useful alternative to immunofluorescence for detecting specific Epstein-Barr virus IgG. ${ }^{6}$

In the present study a simple immunoperoxidase

Accepted for publication 12 December 1983 assay was developed for the detection of specific Epstein-Barr virus IgA to viral capsid antigen and early antigen. The immunoperoxidase technique for specific Epstein-Barr virus IgA was compared with the immunofluorescence technique with respect to its sensitivity and specificity.

\section{Material and methods}

PATIENTS AND SERA

Nine sera from patients with anaplastic nasopharyngeal carcinoma were studied. Six sera were kindly supplied by Professor I Sarov, Beer Sheva, Israel, and three sera were from patients recently diagnosed at $\mathrm{S}$ Orsola Hospital, Bologna.

Eighteen patients with infectious mononucleosis were also studied. The diagnosis was based on the clinical picture, heterophile antibody test, and Epstein-Barr virus serological profile. Serum samples for IgA detection were taken in the second week of illness from all patients. Further serum samples were obtained from nine patients six weeks after the onset of illness.

Seventy four children (age 3-12 years) with acute lymphoblastic leukaemia and 30 patients who had recently had kidney transplants ${ }^{7}$ were also studied.

Twenty healthy children (age 3-12 years), 20 
healthy adults, and 20 cord blood samples were studied for control purposes.

\section{DETECTION OF ANTIBODY TO EPSTEIN-BARR VIRUS \\ Immunofuorescence}

Class specific IgG and IgM to Epstein-Barr virus viral capsid antigen were detected by an indirect immunofluorescence test as described by Edwards and McSwiggan ${ }^{8}$ using $\mathrm{P}_{3} \mathrm{HR}_{1}-\mathrm{K}$ cells (a clone of the $P_{3} J$ line). Sera positive for IgM to Epstein-Barr virus viral capsid antigen were tested for rheumatoid factor using the Rheuma Wellco test (Wellcome Research Laboratories, Beckenham, England). Antibodies to Epstein-Barr virus early antigen (diffuse component) were detected using Epstein-Barr virus superinfected Raji cells fixed in methanol. Fluorescein conjugated antibodies to human IgG or IgM (Dako, Copenhagen, Denmark) at a dilution of $1 / 40$ or $1 / 10$ respectively were used. We have described these procedures previously. ${ }^{.}$

The assay for $\operatorname{IgA}$ antibodies to Epstein-Barr virus viral capsid antigen and early antigen was similar to the IgG antibody test, but the conjugate used was rabbit antihuman IgA (Dako) at a dilution of $1 / 10$.

\section{Immunoperoxidase assay}

Stored slides were thawed, washed in phosphate buffered saline, and covered with test serum or control serum. After incubation at $37^{\circ} \mathrm{C}$ for $30 \mathrm{~min}$ followed by $15 \mathrm{~min}$ in PBS, the slides were incubated for $30 \mathrm{~min}$ with antihuman $\operatorname{IgA}$ or IgG peroxidase conjugate (Dako, Copenhagen, Denmark) diluted $1 / 10$ or $1 / 40$ respectively. The slides were then washed and the enzymatic activity was measured using a modification of the method of Graham and Karnowsky. ${ }^{1011}$

The freshly prepared substrate solution was made of $4 \mathrm{mg}$ benzidine (Fluka AG, Buchs, Switzerland) dissolved in $0.5 \mathrm{ml}$ acetone, $9.5 \mathrm{ml}$ PBS, and $10 \mu \mathrm{l}$ hydrogen peroxide from $33 \%$ stock solution. The substrate was added for $5 \mathrm{~min}$ at room temperature, and this was followed by washing with PBS.

\section{Results}

Endogenous peroxidase activity did not interfere with the test, and it was therefore not necessary to destroy any endogenous peroxidase before performing the immunoperoxidase assay. About $5 \%$ of $\mathrm{P}_{3} \mathrm{HR}_{1}-\mathrm{K}$ cells and $5-10 \%$ of superinfected Raji cells produced the typical cell staining given by the peroxidase reaction when they were incubated with sera containing IgA antibody to viral capsid antigen or early antigen. The staining intensity changed from a dark blue to pale brown. Crystals were often present at the cell surface.

The Table shows the percentages and the geometric mean titres of $\operatorname{IgG}$ and $\operatorname{IgA}$ antibody to viral capsid antigen and early antigen (diffuse component) detected by the immunoperoxidase assay in patients grouped according to disease. As expected, patients with nasopharyngeal carcinoma showed the highest mean titres of $\operatorname{IgA}$ and $\operatorname{IgG}$ antibodies to viral capsid antigen. IgA antibody to viral capsid antigen was found in 13 patients with infectious mononucleosis $(72 \cdot 2 \%)$. Six weeks after the onset of symptoms four $(44.4 \%)$ of nine patients with infectious mononucleosis from whom a further serum sample was obtained were still viral capsid antigen IgA positive at titres $>8$. Six $(20 \%)$ of 30 kidney transplant patients had IgA to viral capsid antigen as well as $21(28.3 \%)$ of 74 patients with acute lymphoblastic leukaemia. IgA antibody to early antigen was found in six $(66.6 \%)$ patients with nasopharyngeal carcinoma and in two $(2.7 \%)$ patients with acute lymphoblastic leukaemia.

Epstein-Barr virus IgA antibody specific to viral capsid antigen was found in one (5\%) serum sample from 20 healthy adults and in three $(15 \%)$ of 20 serum samples from healthy children; in these children the viral capsid antigen IgA titre was 16 and the viral capsid antigen IgG titres were 512, 1024, and 1024. All three children were negative for viral capsid antigen IgM but positive for IgG to early antigen, with titres ranging between 16 and 64 . Epstein-Barr virus IgA antibody specific to viral capsid antigen was not found in any of 20 cord blood

Incidence and geometric mean titres (GMT) of IgG and IgA antibody to Epstein-Barr virus capsid antigen and early antigen in different groups of patients detected by the immunoperoxidase technique

\begin{tabular}{|c|c|c|c|c|c|c|c|c|c|}
\hline \multirow[t]{3}{*}{ Patients } & \multirow{3}{*}{$\begin{array}{l}\text { No } \\
\text { tested }\end{array}$} & \multicolumn{4}{|c|}{ Antibody to viral capsid antigen } & \multicolumn{4}{|c|}{ Antibody to early antigen } \\
\hline & & \multicolumn{2}{|l|}{$\operatorname{Ig} G$} & \multicolumn{2}{|l|}{$\operatorname{Ig} A$} & \multicolumn{2}{|l|}{$\operatorname{Ig} G$} & \multicolumn{2}{|l|}{$\operatorname{Ig} A$} \\
\hline & & $\begin{array}{l}\text { No positive } \\
(\%)\end{array}$ & $G M T$ & $\begin{array}{l}\text { No positive } \\
(\%)\end{array}$ & $G M T$ & $\begin{array}{l}\text { No positive } \\
(\%)\end{array}$ & $G M T$ & $\begin{array}{l}\text { No positive } \\
\text { (\%) }\end{array}$ & GMT \\
\hline $\begin{array}{l}\text { Nasopharyngeal carcinoma } \\
\text { Infectious mononucleosis } \\
\text { Kidney transplant } \\
\text { Acute lymphoblastic leukaemia }\end{array}$ & $\begin{array}{r}9 \\
18 \\
30 \\
74\end{array}$ & $\begin{array}{l}9(100) \\
18(100) \\
30(100) \\
63(85 \cdot 1)\end{array}$ & $\begin{array}{r}1445 \cdot 4 \\
288 \cdot 4 \\
102 \cdot 3 \\
77 \cdot 6\end{array}$ & $\begin{array}{r}9(100) \\
13(72 \cdot 2) \\
6(20 \cdot 0) \\
21(28 \cdot 3)\end{array}$ & $\begin{array}{l}57 \cdot 5 \\
15 \cdot 8 \\
11 \cdot 7 \\
13 \cdot 7\end{array}$ & $\begin{array}{r}7(77 \cdot 8) \\
14(77 \cdot 7) \\
14(46 \cdot 6) \\
28(37 \cdot 8)\end{array}$ & $\begin{array}{r}223 \cdot 8 \\
41 \cdot 7 \\
17 \cdot 4 \\
42 \cdot 6\end{array}$ & $\begin{array}{l}6(66 \cdot 6) \\
0(-) \\
0(-) \\
2(2 \cdot 7)\end{array}$ & $\begin{array}{l}\frac{44 \cdot 7}{22 \cdot 3} \\
\frac{1}{2}\end{array}$ \\
\hline
\end{tabular}




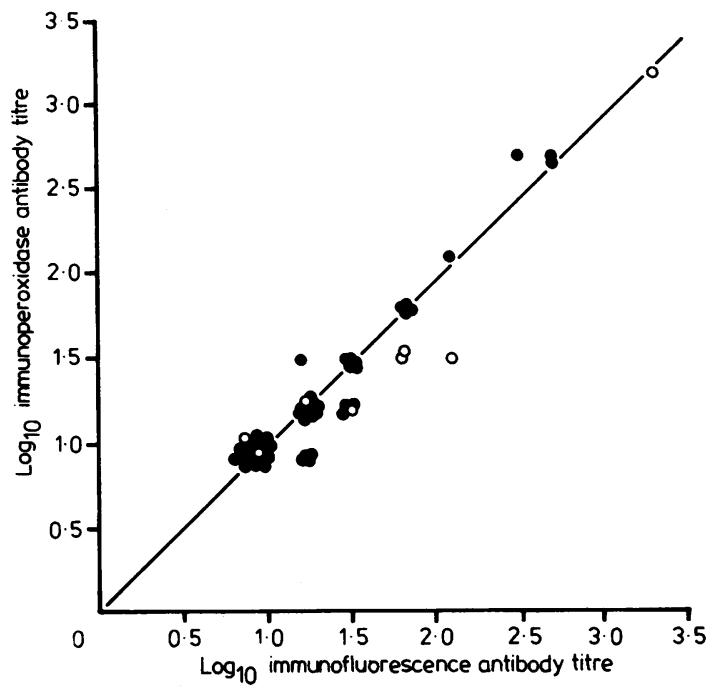

Correlation between antibody titres obtained in patients whose sera were positive for specific IgA antibody to Epstein-Barr virus capsid antigen ( $\bullet$ ) and early antigen ( 0 ) by the immunoperoxidase and immunofuorescence techniques $(n=57 ; y=0.92 \times+0.08 ; r=0.94)$.

samples randomly collected at delivery.

The immunoperoxidase and immunofluorescence titres of the positive sera from patients tested for Epstein-Barr virus specific $\operatorname{IgA}$ antibody to viral capsid antigen and early antigen are compared in the Figure.

\section{Discussion}

The presence of Epstein-Barr virus specific $\operatorname{IgA}$ antibody in serum is a characteristic feature of nasopharyngeal carcinoma. ${ }^{12}{ }^{13}$ Epstein-Barr virus specific serum IgA has also been reported with varying frequency in patients with infectious mononucleosis. ${ }^{14-16}$ In our study Epstein-Barr virus specific IgA antibody as well as IgG antibody to viral capsid antigen were present in all patients with nasopharyngeal carcinoma, who had the highest mean titres: 57.5 and 1445.4 for IgA and IgG respectively.

IgA antibody to viral capsid antigen (mean titre $=$ $15 \cdot 8)$ was also found in $13(72.2 \%)$ of 18 patients with infectious mononucleosis during the second week after the onset of symptoms. Four $(44.4 \%)$ of nine patients from whom a further serum sample was collected were still viral capsid antigen $\operatorname{IgA}$ positive six weeks after the onset of symptoms.

Twenty per cent of kidney transplant patients and $28.3 \%$ of patients with acute lymphoblastic
Cevenini, Donati, Rumpianesi, Moroni, Paolucci

leukaemia were also positive for viral capsid antigen IgA, with geometric mean titres of 11.7 and 13.7 respectively. It has already been established that transplant patients ${ }^{17}$ as well as patients with neoplastic diseases, including leukaemia, ${ }^{18}$ often reactivate Epstein-Barr virus. The patients with acute lymphoblastic leukaemia and the kidney transplant patients whom we studied did not have a primary Epstein-Barr virus infection, but probably had a reactivation of an endogenous virus or an exogenous reinfection. In fact, the patients with acute lymphoblastic leukaemia and the kidney transplant patients who were positive for IgA to viral capsid antigen were also early antigen IgG and viral capsid antigen IgG positive. On the other hand they did not have viral capsid antigen IgM or heterophile antibody in their serum (unpublished data). This means that an endogenous reactivated Epstein-Barr virus or an exogenous reinfection or both, in cases other than nasopharyngeal carcinoma, may stimulate the production of $\operatorname{IgA}$ antibody to viral capsid antigen. Among healthy Epstein-Barr virus seropositive children, $15 \%$ had $\operatorname{IgA}$ antibody to viral capsid antigen in association with IgG to early antigen. The presence of $\operatorname{IgA}$ to viral capsid antigen may reflect, in these cases, a reactivated Epstein-Barr virus infection, since the children were viral capsid antigen IgM negative. IgA antibody to early antigen was detected in $66.6 \%$ of patients with nasopharyngeal carcinoma, in agreement with data previously reported by others ${ }^{19}$ using immunofluorescence, and in only two $(2.7 \%)$ patients with acute lymphoblastic leukaemia.

The results obtained in this study using the immunoperoxidase technique confirm that the detection of $\operatorname{IgA}$ antibody to viral capsid antigen may be used as a test in the serology of infectious mononucleosis, since $72-86 \%$ of the patients with the disease have IgA to viral capsid antigen. In addition, $\operatorname{IgA}$ antibody to viral capsid antigen may be, to some extent, a marker of an active Epstein-Barr virus infection, either primary (that is, infectious mononucleosis) or reactivated, as seen in patients with acute lymphoblastic leukaemia and in kidney transplant patients.

The immunoperoxidase assay technique for Epstein-Barr virus IgA antibody to viral capsid antigen and early antigen was simple and rapid to perform, and correlated well with the immunofluorescence assay $(r=0: 94)$. Antigen can be stored frozen for long periods, which makes it easily available for diagnostic laboratories. Some advantages of the immunoperoxidase technique over immunofluorescence are that permanent slides are produced and expensive fluorescence microscopes are not required. 
The valuable supply of sera from patients with nasopharyngeal carcinoma by Professor I Sarov (Beer Sheva, Israel) is gratefully acknowledged. In addition, we thank Mr Loredano Franchi and $\mathrm{Mr}$ Vittorio Sambri for excellent technical work.

This research was partially supported by grant no 83.00662.52 CNR.

\section{References}

' Henle G. Henle W, Diehl W. Relation of Burkitt tumor associated herpes-type to infectious mononucleosis. Proc Nat Acad Sci USA 1968;59:94-101.

${ }^{2}$ Henle W, Henle G. Seroepidemiology of the virus. In: Epstein MA, Achong BG, eds. Epstein-Barr virus. New York: Springer-Verlag, 1979:62-74.

${ }^{3}$ Henle W, Henle G, Horwitz CA. Infectious mononucleosis and Epstein-Barr virus associated malignancies. In: Lennette EH, Schmidt NJ, eds. Diagnostic procedures for viral, rickettsial and clamydial infections, 5th ed. Washington DC: American Public Health Association, 1979:441-64.

4 Schmitz H. Detection of immunoglobulin $M$ antibody to Epstein-Barr virus by use of an enzyme-labelled antigen. $J$ Clin Microbiol 1982;16:361-6.

${ }^{5}$ Lennette ET, Mard B, Henle G, Henle W. Detection of antibodies to Epstein-Barr virus capsid antigen by immune adherence hemagglutination. J Clin Microbiol 1982;15:69-73.

- Kurstak E, deThé G, van deer Hurk, et al. Detection of Epstein-Barr virus antigens and antibodies by peroxidase labelled specific immunoglobulins. J Med Virol 1978;2:189 200.

${ }^{7}$ Carpi C, Donati M, Musiani M, Zerbini M, Cevenini R, Feletti C. Serum antibody profile against herpes-viruses in renal transplant recipients. Boll Ist Sieroter Milan 1982;61:245-7.

${ }^{8}$ Edwards JMB, McSwiggan DA. Studies on the diagnostic value of an immunofluorescence test for Epstein-Barr virus specific IgM. J Clin Pathol 1974;27:647-51.

- Cevenini R, Donati M, Rumpianesi F, et al. Primary EpsteinBarr virus infection in children with malignant disorders.
Effect of therapy on Epstein-Barr virus antibodies. $J$ Infect 1982;5:73-9.

${ }^{10}$ Cevenini R, Rumpianesi F, Donati M, Sarov I. A rapid immunoperoxidase assay for the detection of specific IgG antibodies to Chlamydia trachomatis. J Clin Pathol 1983;36: 353-6.

" Cevenini R, Donati M, Moroni A, Franchi L, Rumpianesi F. Rapid immunoperoxidase assay for the detection of respiratory syncytial virus in nasopharyngeal secretions. J Clin Microbiol 1982;18:947-9.

${ }^{12} \mathrm{Ho} \mathrm{HC}, \mathrm{Ng} \mathrm{MH}$, Kwan HC, Chan ICW. Epstein-Barr virus specific IgA and IgG serum antibodies in nasopharyngeal carcinoma. Br J Cancer 1976;34:655-9.

${ }^{13}$ Henle G, Henle W. Epstein-Barr virus specific IgA serum antibodies as an outstanding feature of nasopharyngeal carcinoma. Int J Cancer 1976;17:1-7.

${ }^{14}$ Edwards JMB, Woodroof M. Epstein-Barr virus-specific IgA in serum of patients with infectious mononucleosis and of healthy people of different ages. J Clin Pathol 1979;32:1036-40.

is Nikoskelainen J, Neel EU, Stevens DA. Epstein-Barr virus specific serum immunoglobulin $A$ as an acute phase antibody in infectious mononucleosis. J Clin Microbiol 1979;10:75-9.

${ }^{16}$ Evans AS, Niederman JC. Epstein-Barr virus IgA and new heterophile antibody tests in diagnosis of infectious mononucleosis. Am J Clin Pathol 1982;77:555-60.

17 Marker SC, Ascher NL, Kalis JM, Simmons RL, Najarian JS, Balfour HH. Epstein-Barr virus antibody responses and clinical illness in renal transplant recipients. Surgery 1979; 85: $433-40$.

18 Johansson B, Klein G, Henle W, Henle G. Epstein-Barr (EBV) associated antibody patterns in malignant lymphoma and leukaemia. II. Chronic lymphocytic leukaemia and lymphocytic lymphoma. Int J Cancer 1971;8:475-86.

${ }^{19}$ Henle W, Ho JH, Henle G, Chau JC, Kwan HC. Nasopharyngeal carcinoma: significance of changes in Epstein-Barr virusrelated antibody patterns following therapy. Int $J$ Cancer 1977;20:663-72.

Requests for reprints to: $\operatorname{Dr} \mathrm{R}$ Cevenini, Institute of Microbiology, Ospedale S Orsola, 9 Via Massarenti, 40138 Bologna, Italy. 